\title{
Ligation of the intersphincteric fistula tract (LIFT) to treat anal fistula: early results from a prospective observational study
}

\author{
P. Sileri - L. Franceschilli • G. P. Angelucci • \\ S. D'Ugo • G. Milito • F. Cadeddu • I. Selvaggio • \\ S. Lazzaro $\cdot$ A. L. Gaspari
}

Received: 29 June 2011 / Accepted: 9 October 2011/Published online: 11 November 2011

(C) Springer-Verlag 2011

\begin{abstract}
Background Ligation of the intersphincteric tract (LIFT), a novel sphincter-saving technique, has been recently described with promising results. Literature data are still scant. In this prospective observational study, we present our experience with this technique.

Methods Between October 2010 and April 2011, 18 patients with 'complex' fistulas underwent LIFT. All patients were enrolled in the study after a physical examination including digital examination and proctoscopy. For the purpose of this pilot study, fistulas were classified as complex if any of the following conditions were present: tract crossing more than $30 \%$ of the external sphincter, anterior fistula in a woman, recurrent fistula or pre-existing incontinence. Endpoints were healing time, presence of recurrence, faecal incontinence and surgical complications. Results Ten patients were men and 8 were women; mean age was 39 years; minimum follow-up was 4 months. Three patients required drainage seton insertion and delayed LIFT. After LIFT, 1 patient experienced haemorrhoidal thrombosis. At the end of the follow-up, 15 patients $(83 \%)$ healed with no recurrence. Three patients had persistent symptoms and required further surgical treatment. We did not observe postoperative worsening of continence. Conclusions Results from our pilot study indicate that this novel sphincter-saving approach is effective and safe for treating complex anal fistula.
\end{abstract}

P. Sileri $(\bowtie) \cdot$ L. Franceschilli · G. P. Angelucci - S. D’Ugo ·

G. Milito · F. Cadeddu - I. Selvaggio · S. Lazzaro ·

A. L. Gaspari

Department of Surgery, University of Rome Tor Vergata,

Policlinico Tor Vergata, Chirurgia Generale (6B),

Viale Oxford 81, 00133 Rome, Italy

e-mail: piersileri@yahoo.com
Keywords Complex anal fistula - LIFT · Recurrence · Incontinence

\section{Introduction}

The management of fistula-in-ano aims at minimizing recurrences while maintaining continence. Reported recurrence and incontinence rates range from 0 to $32 \%$ and from 0 to $63 \%$, respectively $[1,2]$. These wide ranges depend on many factors, but the surgical technique is the major one. As a matter of fact, no single technique is appropriate for the treatment of all fistulas, and the surgeon's experience and judgement should guide treatment decision. Low fistulas, where the tract is submucosal, intersphincteric or located in the lower third of the external anal sphincter, are usually treated by fistulotomy with low recurrence rates and relatively little impact on incontinence [3-5]. On the other hand, surgical treatments for high and complex fistulas may result in variable degree of anal sphincter impairment. Various alternative surgical options, such as flap repair, fibrin glue injection, seton drainage and fistula track plug insertion with variable success rates, have been proposed [6-9]. Usually, less invasive approaches do not jeopardize continence, but healing rates can be very low. Nowadays, flap repair remains the 'gold standard' for the treatment of high trans-sphincteric perianal or complex fistulas even though a recurrence rate of approximately $30 \%$ can be commonly observed, leaving much room for improvement [10].

Recently, a novel sphincter-saving technique consisting of ligation of the intersphincteric tract (LIFT) has been added to the armamentarium for the management of 'complex' anal fistulas. The initial report in 2006 from Rojanasakul et al. [11] showed a $94 \%$ healing rate with a 
3-month follow-up. Since then, only a few studies of the use of this technique have been reported, mainly published as abstracts, and with variable success rates from 57 to $89 \%$ [12-15]. This intuitive technique is based on the concept of secure closure of the internal opening and concomitant removal of infected cryptoglandular tissue in the intersphincteric plane. Recently, a variation of the technique with interposition of prosthetic biological material to reinforce the closure of the fistula tract has been proposed for complex anal fistula including rectovaginal fistula with healing rates between 81 and $92 \%$ [16].

In this observational prospective study, we report our experience with this novel approach.

\section{Materials and methods}

Between October 2010 and April 2011, 18 consecutive patients underwent the LIFT procedure for complex anal fistula in our institution. Inclusion criteria for this study were age between 18 and 75 years and the presence of a complex anal fistula:/fistula tract crossing more than $30 \%$ of the external sphincter (high trans-sphincteric), anterior fistula in a woman (rectovaginal), recurrent fistula or preexisting incontinence. Fistulas associated with inflammatory bowel disease were excluded from this preliminary experience with LIFT.

All patients underwent outpatient clinic evaluation including digital rectal examination and proctoscopy. For the purpose of this study, all patients underwent preoperative MRI and/or endoscopic ultrasound.

Faecal incontinence was evaluated using the faecal incontinence severe index (FISI), and patients with a score $>6$ underwent anal manometry evaluation per the standard protocol.

Patients with a recent history of anal abscess and fistula or active infection underwent drainage seton insertion and delayed LIFT after 6-8 weeks. When needed, an enema was administered to the patient on the day of the operation. All patients underwent surgery under general anaesthesia in the lithotomy position, and broad-spectrum antibiotics were given at induction. The internal orifice was found using oxygen peroxide injection $\left(\mathrm{H}_{2} \mathrm{O}_{2}\right)$ through the external opening and gently probed to identify the fistula tract. At this point, a non-cutting seton was placed for adequate drainage of the sepsis. The patient was followed up routinely as an outpatient.

Surgery was performed in a day surgery setting, under general anaesthesia and local anaesthesia with patient in the lithotomy position. If a draining seton was present, it was removed, and the fistula tract was irrigated with $\mathrm{H}_{2} \mathrm{O}_{2}$ and saline and then was curetted. If no seton was present, the internal orifice was identified directly by the injection of $\mathrm{H}_{2} \mathrm{O}_{2}$. In case of failure of $\mathrm{H}_{2} \mathrm{O}_{2}$ injection, the internal orifice was identified by the gentle use of a metallic probe. The intersphincteric groove was then identified, and a small circumanal incision $(2 \mathrm{~cm})$ overlying the fistula tract was made to enter the space between the internal and external sphincters. Diathermy and blunt dissection were used to dissect the intersphincteric plane and reach the probed fistula tract. The dissection was kept as close as possible to the internal anal sphincter (IAS), and two small retractors were used to open the space, gently separating the sphincters. The fistula tract was then encircled using a right-angle clamp, and two absorbable sutures (3-0 vicryl) were used to doubly secure and close the fistula tract as close as possible to the lateral margin of IAS and the medial margin of the external anal sphincter (EAS). At this point, the tract between these two sutures was divided, excised for few millimetres and sent for pathologic examination. In order to confirm the closure of both the internal and external fistula tract, $\mathrm{H}_{2} \mathrm{O}_{2}$ was injected from the internal and the external orifices. The intersphincteric plane was then irrigated with $\mathrm{H}_{2} \mathrm{O}_{2}$ and saline, checked for haemostasis and closed in two layers (muscle approximation and skin) using interrupted 3-0 vicryl. The external and internal orifices were left open to allow drainage. Antibiotic prophylaxis consisted of second-generation cephalosporin and metronidazole for 5 days after surgery.

After discharge, patients were followed up 1,2 and 4 weeks after surgery and then routinely every month for the first 6 months.

\section{Results}

Between October 2010 and April 2011, 18 patients with complex anal fistula were treated. Ten patients were men and 8 were women; mean age was 39 years (range 4-62 years). Symptoms lasted from 9 weeks to 32 months (median: 8 months). Fifteen patients presented high transsphincteric fistulas, two rectovaginal fistulas and one a history of horseshoe abscess. Four patients reported recurrent fistulas ( $>3$ surgeries: 2 patients, 1-2 surgeries: 2 patients). One patient reported preoperative incontinence to gas. Three patients required drainage seton insertion and delayed LIFT because of active infection and/or multiple tracts.

Median follow-up was 6 months (range 4-10 months).

All operations were uneventful day surgery procedures, and patients were discharged home as scheduled. During the first week, 1 patient experienced haemorrhoidal thrombosis that was successfully treated conservatively.

At the end of follow-up, 15 patients (83\%) had healed with no recurrence. In these cases, wounds healed completely during the first 6 weeks. Three patients had 
Table 1 Worldwide experience with LIFT

\begin{tabular}{|c|c|c|c|c|c|}
\hline Author [ref] & $\mathrm{N}$ pts & $\begin{array}{l}\mathrm{N} \text { patients } \\
\text { Cryptoglandular/IBD }\end{array}$ & Follow-up & Healing rates & Complications \\
\hline Present series & 18 & No IBD & 6 months & $15 / 18(83.3 \%)$ & $\begin{array}{l}\text { No changes in continence } \\
1 \text { haemorrhoidal thrombosis }\end{array}$ \\
\hline Abcarian et al. [15] & 25 & $24 / 1$ & 8 weeks & $\begin{array}{l}16 / 21 \text { (tot pts at FU) } \\
76 \% \text { overall success rate } \\
100 \% \text { success rate in pts } \\
\text { LIFT 1st procedure }\end{array}$ & No changes in continence \\
\hline Neal Ellis [16] & 31 & No IBD & $>1$ year & $29 / 31(94 \%)$ & No incontinence \\
\hline Aboulian et al. [12] & 25 & NR & 24 weeks & $17 / 25(68 \%)$ & $\begin{array}{l}\text { No incontinence } \\
2 \text { vaginal fungal infections }\end{array}$ \\
\hline Shanwani et al. [13] & 45 & $\begin{array}{l}\text { No IBD } \\
\text { No IBD }\end{array}$ & 9 months & $37 / 45(82.2 \%)$ & $\begin{array}{l}\text { No incontinence } \\
\text { No complication }\end{array}$ \\
\hline Bleier et al. [14] & 39 & NR & 20 weeks & $20 / 35$ (tot pts at FU) $57 \%$ & $\begin{array}{l}\text { No incontinence } \\
1 \text { anal fissure } \\
1 \text { chronic anal pain }\end{array}$ \\
\hline Rojanasakul [11] & 18 & No IBD & 3 months & $17 / 18(94.4 \%)$ & No incontinence \\
\hline
\end{tabular}

$I B D$ inflammatory bowel disease, $F U$ follow-up. $N R$ not recorded

persistent symptoms and required further surgical treatment. One patient underwent fistulotomy since the trans-sphincteric tract was downstaged to an intersphincteric fistula through the incision. The other two patients were treated with seton insertion and subsequent advancement flap.

We did not observe postoperative worsening of continence.

\section{Discussion}

Main concepts in the treatment of anal fistula are the removal of the infected cryptoglandular tissue in the intersphincteric plane and the closure of the internal opening. The chronic intersphincteric anal gland infection is believed to be associated with the aetiology and the persistence of idiopathic anal fistula [17]. As a matter of fact, Parks advocated a technique of removal of infected cryptoglandular tissue by laying open the IAS below the internal opening. Despite this, it never gained popularity [18]. The closure of the internal orifice is the mainstay of all surgical procedures, aiming to eliminate the source of persisting anal fistula where faecal material is forced through. The LIFT procedure combines the two key concepts: removal of the infected cryptoglandular tissue and closure of the internal orifice with negligible trauma to the sphincterial apparatus. As indicated by Lunniss et al. [19], a similar approach was pioneered by Phillips who described an IAS- and EAS-conserving surgical approach through the intersphincteric plane with curettage of sepsis, closure of the internal opening at this level, excision of tracks lateral to the plane with closure of the resultant hole in the external sphincter, and primary closure. In 1993, he treated 13 complex anal fistula patients with this conservative approach (including patients with Crohn's disease) and reported only one failure [18]. Despite being similar to LIFT, this approach did not gain popularity.

Since the first description of LIFT in 2006, only a few experiences have been reported in the literature with variable results and indications. Success rates range from 57 to $94 \%$ with variable follow-up [12-15] as shown in Table 1. Overall, a pooled cumulative success rate of $74 \%$ can be drawn from this worldwide experience. Our success rate of $83.3 \%$ is comparable to the healing rates at other experienced centres.

According to our experience and the literature, failures can often be easier to treat since a downstage of the fistula can be observed through the trans-sphincteric plane thus involving only the internal sphincter.

Moreover, LIFT seems to be very safe in terms of morbidity. We did observe a single episode of haemorrhoidal thrombosis, and reviewing the literature found that complication rates are negligible and continence is invariably respected as shown in Table 1.

Another advantage of LIFT is the very low cost of the procedure since no foreign infill or plug materials are used. Our experience and the initial literature evidence support LIFT cost effectiveness with better results compared to plug or glue use alone even if a two-step surgical approach is adopted with delayed LIFT after seton insertion. LIFT can also be repeated in case of failure with good results [12]. 


\section{Conclusions}

Based on the results of our study, the LIFT procedure appears to be safe, effective and cost effective. Longerterm data are needed to better evaluate the exact role of LIFT in the treatment of complex fistulas.

Conflict of interest The authors declare that no conflict of interest exists.

\section{References}

1. Rojanasakul A (2009) LIFT procedure: a simplified technique for fistula in ano. Tech Coloproctol 13:237-240

2. Garcia-Aguilar J, Belmonte C, Wang WD, Goldberg SM, Madoff RD (1996) Anal fistula surgery. Factors associated with recurrence and incontinence. Dis Colon Rectum 39:723-729

3. Whiteford MH, Kilkenny J III, Hyman N et al (2005) The standards practice task force, American Society of Colon and Rectal Surgeons. Practice parameters for the treatment of perianal abscess and fistula-in-ano (revised). Dis Colon Rectum 48:1337-1342

4. Parks AG, Gordon PH, Hardcastle JD (1976) A classification of fistula-in-ano. Br J Surg 63:1-12

5. Seow-Choen F, Nicholls RJ (1992) Anal fistula. Br J Surg 79:197-205

6. Wang JY, Garcia-Aguilar J, Sternberg JA, Abel ME, Varma MG (2009) Treatment of transsphincteric anal fistulas: are fistula plugs an acceptable alternative? Dis Colon Rectum 52:692-697

7. van Koperen PJ, Bemelman WA, Bossuyt PM et al (2008) The anal fistula plug versus the mucosal advancement flap for the treatment of anorectal fistula (PLUG trial). BMC Surg 8:11

8. Soltani A, Kaiser AM (2010) Endorectal advancement flap for cryptoglandular or Crohn's fistula-in-ano. Dis Colon Rectum 53:486-495
9. Ritchie RD, Sackier JM, Hodde JP (2009) Incontinence rates after cutting seton treatment for anal fistula. Colorectal Dis 11:564-571

10. Sileri P, Franceschilli L, Del Vecchio Blanco G, Stolfi VM, Angelucci GP, Gaspari AL (2011) Porcine dermal collagen matrix injection may enhance flap repair surgery for complex anal fistula. Int J Colorectal Dis 26:345-349

11. Rojanasakul A, Pattanaarun J, Sahakitrungruang C, Tantiphlachiva K (2007) Total anal sphincter saving technique for fistulain-ano: the ligation of intersphincteric fistula tract. J Med Assoc Thai 90:581-586

12. Aboulian A, Kaji AH, Kumar RR (2011) Early result of ligation of the intersphincteric fistula tract for fistula-in-ano. Dis Colon Rectum 54:289-292

13. Shanwani A, Nor AM, Amri N (2010) Ligation of intersphincteric fistula tract (LIFT): a sphincter-saving technique in fistulain-ano. Dis Colon Rectum 53:39-43

14. Bleier JI, Moloo H, Goldberg SM (2010) Ligation of the intersphincteric fistula tract: an effective new technique for complex fistulas. Dis Colon Rectum 53:43-46

15. Abcarian H, Estrada J, Weisman R et al (2011) The ligation of intersphincteric fistula tract: a pilot study. Abstract ASCRS Annual Scientific Meeting

16. Neal Ellis C (2010) Outcomes with the use of bioprosthetic graft to reinforce the ligation of the intersphincteric fistula tract (BioLIFT procedure) for the management of complex anal fistulas. Dis Colon Rectum 53:1361-1364

17. Parks AG (1961) The pathogenesis and treatment of fistula-inano. Br Med J 1:463-469

18. Matos D, Lunniss PJ, Phillips RKS (1993) Total sphincter conservation in high fistula in ano: results of a new approach. Br J Surg 80:802-804

19. Lunniss PJ (2009) LIFT procedure: a simplified technique for fistula-in-ano. Tech Coloproctol 13:241-242 